\title{
COMPUTER TECHNOLOGIES FOR CONCRETE AIRFIELD PAVEMENT DESIGN
}

\author{
Oleksandr RODCHENKO \\ National Aviation University, Kyiv, Ukraine \\ E-mail: rodchenko@nau.edu.ua
}

Received 04 January 2017; accepted 11 September 2017

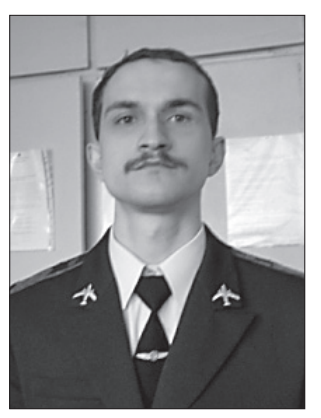

Oleksandr RODCHENKO, Assoc Prof, PhD (Eng)

Education: National Aviation University, 2005.

Affiliations and functions: associate professor of the Computer Technologies of Construction

Department at the National Aviation University.

Research interests: airfield rigid pavement design.

Publications: author of over 50 publications.

\begin{abstract}
The purpose of the research is to develop formulas, expressions and a computer program for concrete airfield pavement design under the impact of all Airbus 380 main landing gears taking into consideration the design factor of tensile stresses at the top and bottom of a concrete slab. The top-down cracking in concrete slabs has not been directly simulated in structural analysis models used for one- and two-layer concrete airfield pavement design by the Ukrainian Standard. Empirical formulas for the calculation of top tensile stress and the coverages to failure using the criterion of top tensile stress are obtained. Computer program "Aerodrom 380" has been developed for the design of concrete airfield pavement thickness. It provides the required thickness of a concrete slab needed to support an Airbus 380 over a particular subgrade and uses the bottom and top tensile stresses as design factors. "Aerodrom 380" contains a fatigue function for determining the number of coverages to failure permissible for a concrete slab before it has top-bottom and bottom-up cracks. The results obtained with this program are compared to other solutions using the Ukrainian Standard SNiP 2.05.08-85, "LIRA-SAPR", software and the FAARFIELD computer program. The anticipated life of a concrete airfield pavement calculated using computer program "Aerodrom 380 " is about $70 \%$ of the FAARFIELD pavement life.
\end{abstract}

Keywords: concrete airfield pavement, airfield rigid pavement, design factor, aircraft, main landing gear, flexural strength, fatigue failure, top tensile stress, bottom tensile stress.

\section{Introduction}

In Ukraine, the conventional rigid pavement of international airports is a two-layer concrete pavement on a stabilized base. The improvement of the two-layer rigid pavement design is important, especially for pavement analysis under the impact of the main landing gears of new large wide-body aircraft such as the A380800 (WV000-009).

The purpose of this research is to develop the formulas, expressions, and a computer program for concrete airfield pavement design under the impact of the A380-800 main landing gears, taking into consideration tensile stresses at the top and bottom of a concrete slab as the design factor.
The top-down cracking in concrete slabs has not been directly simulated in structural analysis models used for one- and two-layer concrete airfield pavement design by the Ukrainian Standard (SNiP 2.05.08-85).

\section{Concrete airfield pavement design software and standards}

In the Ukrainian Standard (SNiP 2.05.08-85), concrete pavement thickness design is performed by using an infinite slab model with wheel loads placed on its center. Free-edge stress equals interior stress multiplied by transition factor $k=1.5$. If the PCC slab has joints, the edge stress is equal to the interior stress multiplied by transition factor $k=1.2$. The Ukrainian Standard 
uses tensile stress at the bottom of a concrete slab as the design factor.

Computer program FAARFIELD (Federal Aviation Administration Rigid and Flexible Iterative Elastic Layered Design) was developed by the FAA (Federal Aviation Administration) USA. It designs the slab thickness based on the assumption of edge loading. The gear load is located either tangent or perpendicular to the slab edge, and the larger of the two stresses (reduced by 25 percent to account for load transfer through the joint) is taken as the design stress for determining the slab thickness (Guo 2013; AC 150/5320-6E). The program computes only the thickness of the concrete layer. The major features of FAARFIELD are: a 1-slab rigid pavement model, infinite subgrade model, arbitrary gear loading capability, and failure model. FAARFIELD uses tensile stress at the bottom edge of a concrete slab as a design factor (AC 150/5320-6E). Top-down cracking due to edge or corner loading is not included in the design using FAARFIELD (AC 150/5320-6E; Davis 2012).

The assessment of the impact of aircraft full main landing gears is not supported by the Ukrainian Standard (SNiP 2.05.08-85) and FAARFIELD (AC 150/5320$6 \mathrm{E})$.

\section{Top-down cracking}

Full-scale rigid pavement tests at the National Airport Pavement Test Facility (NAPTF) of the FAA and the Airbus Pavement Experimental Program (PEP) have shown that top-down cracking can occur under the loading of all main landing gears (Airbus 2005; Ricalde 2007; Davis 2012). Guo (Guo et al. 2002) analysed the results of the NAPTF tests and observed that top-down cracks occurred in the longitudinal direction when the main landing gears moved near transverse joints. The top-down cracks occur when the strains measured at the top of the concrete slab are lower than the strains at the bottom of the slab (Guo, Pecht 2007). The obtained results are explained by Fabre (Fabre, Balay 2008). The strength at the top of the concrete slab could be 35 percent lower than at the bottom. The generalized longitudinal median crack (top to bottom) observed at the surface of the slabs trafficked by the two A380 bogies during the fatigue campaign of PEP should be related to high tensile stresses at the top of the slab (Airbus 2005).

The effects of aircraft main landing gear configurations and the locations of airfield rigid pavement slabs are analyzed by Guo and Pecht. They focus on analyzing concrete pavement behavior based on test data and finite element analysis (Guo, Pecht 2006). Roesler obtained the key slab loading locations on an airfield's rigid pavement which alter the critical tensile stress at the top of the concrete slab (Roesler et al. 2007; Evangelista, Roesler 2008). The ratio of top to bottom tensile stress is significantly higher for the full main landing gear analysis relative to the individual gear analysis (Roesler, Evangelista 2010). Critical top tensile stress is created when the main landing gears of the Airbus 380 straddle multiple adjacent slabs (Roesler et al. 2007).

\section{Computer program "Aerodrom 380"}

Computer program "Aerodrom 380" (in Ukrainian) has been developed for concrete airfield pavement design. It is written in Visual C++ 2008. "Aerodrom 380" has a certificate of recognition (Avtorske ... 2014). The program provides the required thickness of a concrete slab needed to support the Airbus 380 over a particular subgrade.

"Aerodrom 380" uses the maximum tensile stress at the bottom and top edge of the concrete slab as the design factor. The maximum tensile stress at the bottom edge of the concrete slab (free-edge stress) equals the interior stress multiplied by transition factor $k=1.5$ (SNiP 2.05.08-85). If the concrete slab has joints, the edge stress is equals the interior stress multiplied by transition factor $k=1.2$ (SNiP 2.05.08-85). The interior stress at the bottom of the slab is determined using an interior loading condition.

The interior bending moment can be determined by using the following expression:

$$
\begin{aligned}
& M_{\mathrm{int}}=\frac{V_{W G} k_{d} \gamma_{f}}{4}\left[0.1154-0.0902 \cdot \ln \left(\frac{\sqrt{\frac{V_{W G} k_{d} \gamma_{f}}{4000 \cdot \pi p_{a}}}}{l}\right)\right]- \\
& \frac{V_{W G} k_{d} \gamma_{f}}{4}\left[0.1506 \cdot \ln \frac{1.35}{l}+0.0873 \cdot \ln \frac{1.7}{l}\right]+ \\
& \frac{0.0018 \cdot V_{W G} k_{d} \gamma_{f} e^{\frac{1,7}{l}}}{4},
\end{aligned}
$$

where $V_{W G}$ is the maximum vertical wing gear ground load, kN (Airbus 2014); $k_{d}$ - dynamic ratio, its value must be applied according to the Ukrainian Standard (SNiP 2.05.08-85); $\gamma_{f}$ - derating factor, its value must be applied according to the Ukrainian Standard (SNiP 2.05.08-85); $p_{a}$ - tire pressure, MPa (Airbus 2014); $l$ radius of relative stiffness, $m$. The radius of the relative stiffness of a two-layer concrete pavement on a stabilized base is determined according to the Ukrainian Standard (SNiP 2.05.08-85).

The maximum tensile stress at the top edge of the upper concrete slab is determined as follows:

$$
\sigma_{T, u p}=\sigma_{u p}\left(0.048 \ln K_{s}+0.457\right),
$$

where: $\sigma_{u p}$ is the maximum tensile stress at the bottom edge of the upper concrete slab, $\mathrm{MPa} ; K_{s}$ - subgrade ratio, $\mathrm{MN} / \mathrm{m}^{3}$. 
The maximum bottom tensile stress can be determined by using a formula obtained according to Ukrainian Standard data (SNiP 2.05.08-85):

$$
\begin{gathered}
\sigma_{u p}=\frac{0.006 E_{u p} h_{u p}}{E_{u p} h_{u p}^{3}+E_{l w} h_{l w}^{3}+E_{s b} h_{s b}^{3}} \cdot M_{\mathrm{int}} k \times \\
{\left[1-0.167\left(0.791-0.141 \ln \frac{E_{u p} h_{u p}^{3}+E_{l w} h_{l w}^{3}}{E_{s b} h_{s b}^{3}}\right)\right],}
\end{gathered}
$$

where: $E_{u p}$ is the Young's Modulus of the upper concrete slab, MPa; $E_{l w}$ - Young's Modulus of the lower lean concrete slab, MPa; $E_{s b}$ - Young's Modulus of the stabilized base, MPa; $h_{u p}$ - upper concrete slab thickness, $\mathrm{m} ; h_{l w}-$ lower lean concrete slab thickness, $\mathrm{m} ; h_{s b}$ - stabilized base thickness, $\mathrm{m} ; M_{\text {int }}$ - interior bending moment, $\mathrm{kN} \cdot \mathrm{m} / \mathrm{m} ; k$ - transition factor.

The maximum tensile stress at the top edge of the lower lean concrete slab is determined as follows:

$$
\sigma_{T, l w}=\sigma_{l w}\left(0.088 \ln K_{s}+0.439\right),
$$

where: $\sigma_{l w}$ is the maximum tensile stress at the bottom edge of the lower lean concrete slab, $\mathrm{MPa} ; K_{s}$ - subgrade ratio, $\mathrm{MN} / \mathrm{m}^{3}$.

The maximum bottom tensile stress is determined by using the following formula:

$$
\begin{aligned}
& \sigma_{l w}=\frac{0.006 E_{l w} h_{l w}}{E_{u p} h_{u p}^{3}+E_{l w} h_{l w}^{3}+E_{s b} h_{s b}^{3}} \cdot M_{\mathrm{int}} k \times \\
& {\left[1-0.167\left(0.791-0.141 \ln \frac{E_{l w} h_{l w}^{3}+E_{u p} h_{u p}^{3}}{E_{s b} h_{s b}^{3}}\right)\right],}
\end{aligned}
$$

where: $E_{l w}$ is the Young's Modulus of the lower lean concrete slab, MPa; $E_{u p}$ - Young's Modulus of the upper concrete slab, MPa; $E_{s b}$ - Young's Modulus of the stabilized base, $\mathrm{MPa} ; h_{l w}$ - lower lean concrete slab thickness, $\mathrm{m} ; h_{u p}$ - upper concrete slab thickness, $\mathrm{m} ; h_{s b}$ - stabilized base thickness, $\mathrm{m} ; M_{\text {int }}$ - interior bending moment, $\mathrm{MPa} ; k$ - transition factor.

Computer program "Aerodrom 380" uses a fatigue failure concept that is expressed in terms of a damage ratio (D). It is expressed as the ratio of applied load repetitions to allowable load repetitions. The damage ratio is thus determined by using the FAA's CDF (cumulative damage factor) formula (AC 150/5320-6E). "Aerodrom 380" determines two damage ratios for every structural layer:

$$
\begin{aligned}
& D_{B, u p}=\frac{N \cdot T}{C_{B, u p} \cdot P\left(V_{W G}\right)}, \\
& D_{T, u p}=\frac{N \cdot T}{C_{T, u p} \cdot P_{T}}, \\
& D_{B, l w}=\frac{N \cdot T}{C_{B, l w} \cdot P\left(V_{W G}\right)}, \\
& D_{T, l w}=\frac{N \cdot T}{C_{T, l w} \cdot P_{T}},
\end{aligned}
$$

where: $D_{B, u p}$ is the damage ratio for the design factor expressed as the maximum tensile stress at the bottom edge of the upper concrete slab; $D_{T, u p}$ - damage ratio for the design factor expressed as the maximum tensile stress at the top edge of the upper concrete slab; $D_{B, l w}-$ damage ratio for the design factor expressed as the maximum tensile stress at the bottom edge of the lower lean concrete slab; $D_{T, l w}$ - damage ratio for the design factor expressed as the maximum tensile stress at the top edge of the lower lean concrete slab; $N$ - annual departures; $T$ - design life (20 years); $C_{B, u p^{-}}$the number of coverages to failure or the number of admissible cycles of loads for the design factor expressed as the maximum tensile stress at the bottom edge of the upper concrete slab; $C_{T, u p}$ - the number of coverages to failure (number of admissible cycles of loads) for the design factor expressed as the maximum top tensile stress; $C_{B, l w^{-}}$the number of coverages to failure for the design factor expressed as the maximum tensile stress at the bottom edge of the lower lean concrete slab; $C_{T, l w}$ - the number of coverages to failure for the design factor expressed as the maximum tensile stress at the top edge of the lower lean concrete slab; $P\left(V_{W G}\right)$ - probability factor, similar to the FAA's pass to coverage ratio (PCR), determined by using the HoSang method (HoSang 1975); $P_{T}$ - probability factor for the top edge, equal to 4,15 . The values of probability factor $P\left(V_{W G}\right)$ are calculated for all current Airbus 380 weight variants (Table 1).

The number of coverages to failure can be determined by using Stepushyn's expression (Stepushin 2001):

$$
\begin{aligned}
& C=10^{12[1-f],} \\
& f=\frac{\sigma_{\max }}{\gamma_{c} R},
\end{aligned}
$$

where: $f$ is the degree of the relative mechanical stress level; $\sigma_{\text {max }}-$ maximum tensile stress, $\mathrm{MPa} ; \gamma_{c}$ - service factor; $R$ - standard concrete flexural strength measured on 28 days, $\mathrm{MPa}$.

Table 1 . Probability factor $P\left(V_{W G}\right)$

\begin{tabular}{llll}
\hline $\begin{array}{c}\text { A380-800 } \\
\text { weight } \\
\text { variant }(\mathrm{WV})\end{array}$ & $P\left(V_{W G}\right)$ & $\begin{array}{c}\text { A380-800 } \\
\text { weight } \\
\text { variant (WV) }\end{array}$ & $P\left(V_{W G}\right)$ \\
\hline WV000 & 4.08 & WV005 & 4.08 \\
\hline WV001 & 4.13 & WV006 & 4.05 \\
\hline WV002 & 4.07 & WV007 & 4.21 \\
\hline WV003 & 4.13 & WV008 & 4.05 \\
\hline WV004 & 4.08 & WV009 & 4.13 \\
\hline
\end{tabular}


Stepushyn's expression (8) provides a fatigue function for determining the number of admissible cycles of loads or the number of coverages to failure permissible by a concrete slab before it cracks.

Thus, the number of coverages to failure (the number of admissible cycles of loads), $C_{B, u p}, C_{T, u p}, C_{B, \mathrm{lw}}$ and $C_{T, l w}$, is determined by using the following formulas:

$$
\begin{aligned}
& C_{B, u p}=10^{12\left[1-f_{1}\right],} \\
& f_{1}=\frac{\sigma_{u p}}{\gamma_{c} R_{u p}}, \\
& C_{T, u p}=10^{12\left[1-f_{2}\right],} \\
& f_{2}=\frac{\sigma_{T, u p}}{0.65 \gamma_{c} R_{u p}}, \\
& C_{B, l w}=10^{12\left[1-f_{3}\right]}, \\
& f_{3}=\frac{\sigma_{l w}}{1.28 \gamma_{c} R_{l w}}, \\
& C_{T, l w}=10^{12\left[1-f_{4}\right],} \\
& f_{4}=\frac{\sigma_{T, l w}}{0.832 \gamma_{c} R_{l w}},
\end{aligned}
$$

where: $\sigma_{u p}$ is the maximum tensile stress at the bottom edge of the upper concrete slab, MPa; $\sigma_{T, u p}$ - maximum tensile stress at the top edge of the upper concrete slab, $\mathrm{MPa} ; \sigma_{l w}$ - maximum tensile stress at the bottom edge of the lower lean concrete slab, MPa; $\sigma_{T, l w}$ - maximum tensile stress at the top edge of the lower lean concrete slab, MPa; $\gamma_{c}$ - service factor; $R_{u p}$ - standard concrete flexural strength of the upper concrete slab measured on 28 days, MPa; $R_{l w}$ - standard concrete flexural strength of the lower lean concrete slab, MPa.

The damage ratios must equal 1 . Computer program "Aerodrom 380" determines the maximum damage ratio for the desired conditions, and then performs the concrete slab thickness design. If the damage ratio is lower than 1 , the computer program decreases the upper concrete slab thickness. If the damage ratio is more than 1, "Aerodrom 380" increases the upper concrete slab thickness. Computer program "Aerodrom 380" uses the upper concrete slab thickness in the range of $0.31-0.45$ $\mathrm{m}$. If the upper concrete slab thickness is greater than

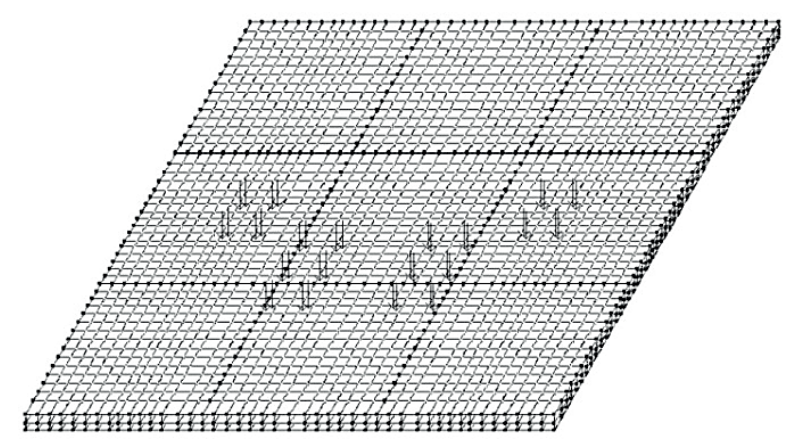

Fig. 1. Finite element model of a two-layer concrete pavement under the impact of an A380-800 main landing gears

$0.45 \mathrm{~m}$, the program calculates the pavement anticipated life, $T_{a l}$

$$
T_{a l}=U / N,
$$

where: $U$ is the number of allowable load repetitions for the maximum damage ratio.

\section{Comparing results of airfield rigid pavement analysis using "Aerodrom 380" and "LIRA-SAPR"}

"LIRA-SAPR" is a general-purpose finite element program that was developed in Kyiv (Ukraine). The multiple-slab jointed rigid pavement model includes nine slabs. Two-dimensional shell finite elements are used to represent the upper and lower concrete slab of a twolayer rigid pavement and a stabilized base. The subgrade model is the Winkler foundation. The upper and lower concrete slabs are unbound layers. The nine-slab jointed two-layer concrete pavement model for the A380-800 case is shown in Figure 1. The nine-slab geometry simulates a parallel taxiway with the width of $22.5 \mathrm{~m}$ that is extended in Ukraine's international airports (Rodchenko 2013, 2014).

The analysis using the the "Aerodrom 380" and "LIRA-SAPR" programs is performed for the following

\begin{tabular}{|c|c|c|c|c|c|c|}
\hline \multirow[t]{2}{*}{$\begin{array}{l}\text { Subgrade ratio } \\
\mathrm{MN} / \mathrm{m}^{3}\end{array}$} & \multicolumn{2}{|c|}{$\begin{array}{l}\text { The maximum tensile stress } \\
\text { at the top and bottom of the upper slab } \\
\text { ("LIRA-SAPR"), MPa }\end{array}$} & \multirow{2}{*}{$\begin{array}{l}\text { Top to } \\
\text { bottom } \\
\text { ratio }\end{array}$} & \multicolumn{2}{|c|}{$\begin{array}{l}\text { The maximum tensile stress } \\
\text { at the top and bottom of the upper slab } \\
\text { ("Aerodrom } 380 \text { "), MPa }\end{array}$} & \multirow{2}{*}{$\begin{array}{l}\text { Top to } \\
\text { bottom } \\
\text { ratio }\end{array}$} \\
\hline & Top & Bottom & & Top & Bottom & \\
\hline 40 & 1.92 & 3.04 & 0.63 & 1.97 & 3.11 & 0.63 \\
\hline 50 & 1.87 & 2.90 & 0.65 & 1.89 & 2.93 & 0.65 \\
\hline 60 & 1.83 & 2.79 & 0.65 & 1.82 & 2.79 & 0.65 \\
\hline
\end{tabular}
case: a 450-mm upper concrete slab (dimensions $7.5 \times 7.5$ $\mathrm{m}, E_{\text {up }}=35300 \mathrm{MPa}$ ), 300-mm lower lean concrete slab $\left(E_{l w}=17000 \mathrm{MPa}\right)$, stabilized base $\left(E_{s b}=7800 \mathrm{MPa}\right)$, and Winkler foundation $\left(40,50\right.$ and $\left.60 \mathrm{MN} / \mathrm{m}^{3}\right)$; the design aircraft is an A380-800 WV000 with the maximum ramp weight of $562 \mathrm{t}$. The results obtained in "LIRASAPR" and "Aerodrom 380" are summarized in Table 2.

Table 2. Comparative results of the "LIRA-SAPR" and "Aerodrom 380" analysis 
The maximum top and bottom tensile stresses coincide in the "LIRA-SAPR" software and the "Aerodrom 380 " computer program. The top to bottom tensile stress ratio increases when the subgrade ratio goes up.

\section{Comparing the results of airport concrete slab thickness design using "Aerodrom 380", SNiP 2.05.08-85 and FAARFIELD}

The analysis of the results obtained by "Aerodrom 380", SNiP 2.05.08-85 and FAARFIELD on the concrete slab thickness design and pavement anticipated life are performed for the following cases.

1. An upper concrete slab $\left(R_{u p}=5.76 \mathrm{MPa}, E_{u p}=\right.$ $35300 \mathrm{MPa}$ ), the service factor of which equals 0.75 (for the runway and parallel taxiway); 300 $\mathrm{mm}$ lower lean concrete slab $\left(R_{l w}=2.09 \mathrm{MPa}\right.$, $\left.E_{l w}=17000 \mathrm{MPa}\right) ; 250$ - $\mathrm{mm}$ stabilized base $\left(E_{s b}=\right.$ $4810 \mathrm{MPa})$, and Winkler foundation (60 MN/ $\mathrm{m}^{3}$ ); the design aircraft is an A380-800 WV002 with the maximum ramp weight of $571 \mathrm{t}$, and 2000 annual departures.

2. An upper concrete slab $\left(R_{u p}=5.76 \mathrm{MPa}, E_{u p}=\right.$ $35300 \mathrm{MPa}$ ), the service factor of which equals 0.75 (for the parallel taxiway); 300-mm lower lean concrete slab $\left(R_{l w}=2.09 \mathrm{MPa}, E_{l w}=\right.$ $17000 \mathrm{MPa})$; $250-\mathrm{mm}$ stabilized base $\left(E_{s b}=\right.$ $3700 \mathrm{MPa})$, and Winkler foundation $(60 \mathrm{MN} /$ $\mathrm{m}^{3}$ ); the design aircraft is an A380-800 WV001 with the maximum ramp weight of $512 \mathrm{t}$, and 5000 annual departures.

3. An upper concrete slab $\left(R_{u p}=5.24 \mathrm{MPa}, E_{u p}=\right.$ $32400 \mathrm{MPa}$ ), the service factor of which equals 0.85 (apron); 200-mm lower lean concrete slab $\left(R_{l w}=2.09 \mathrm{MPa}, E_{l w}=17000 \mathrm{MPa}\right) ; 150-\mathrm{mm}$ stabilized base $\left(E_{s b}=1950 \mathrm{MPa}\right)$, and Winkler foundation $\left(60 \mathrm{MN} / \mathrm{m}^{3}\right)$; the design aircraft is an A380-800 WV001 with the maximum ramp weight of 512 t, and 10000 annual departures.
4. An upper concrete slab $\left(R_{u p}=5.24 \mathrm{MPa}, E_{u p}=\right.$ $32400 \mathrm{MPa}$ ), the service factor of which equals 0.85 (for apron); 300-mm lower lean concrete slab $\left(R_{l w}=2.09 \mathrm{MPa}, E_{l w}=17000 \mathrm{MPa}\right) ; 200-\mathrm{mm}$ stabilized base $\left(E_{s b}=4810 \mathrm{MPa}\right)$, and Winkler foundation $\left(50 \mathrm{MN} / \mathrm{m}^{3}\right)$; the design aircraft is an A380-800 WV001 with the maximum ramp weight of $512 \mathrm{t}$, and 5000 annual departures.

5. An upper concrete slab $\left(R_{u p}=5.24 \mathrm{MPa}, E_{u p}=\right.$ $32400 \mathrm{MPa}$ ), the service factor of which equals 0.90 (for apron); 250-mm lower lean concrete $\operatorname{slab}\left(R_{l w}=2.09 \mathrm{MPa}, E_{l w}=17000 \mathrm{MPa}\right) ; 200-\mathrm{mm}$ stabilized base $\left(E_{s b}=1950 \mathrm{MPa}\right)$, and Winkler foundation $\left(40 \mathrm{MN} / \mathrm{m}^{3}\right)$; the design aircraft is an A380-800 WV007 with the maximum ramp weight of $492 \mathrm{t}$, and 2000 annual departures.

The results obtained using SNiP 2.05.08-85, FAARFIELD and "Aerodrom 380" are summarized in Table 3.

The upper concrete slab thickness calculated by computer program "Aerodrom 380" is greater than the slab thickness calculated by FAARFIELD. Its maximum deviation is about $5 \%$ (see Table 3 ).

Using "Aerodrom 380" and FAARFIELD (Table 4), a pavement anticipated life analysis was performed for the following pavements designed by using the SNiP 2.05.08-85.

1. A $450-\mathrm{mm}$ upper concrete slab $\left(R_{u p}=5.76 \mathrm{MPa}\right.$, $\left.E_{u p}=35300 \mathrm{MPa}\right)$, the service factor of which equals 0.75 (for the parallel taxiway); 300-mm lower lean concrete slab $\left(R_{l w}=2.09 \mathrm{MPa}, E_{l w}=\right.$ $17000 \mathrm{MPa}) ; 250-\mathrm{mm}$ stabilized base $\left(E_{s b}=\right.$ $4810 \mathrm{MPa}$ ), and Winkler foundation (60 MN/ $\mathrm{m}^{3}$ ); the design aircraft is an A380-800 WV002 with the maximum ramp weight of $571 \mathrm{t}$, and 5000 annual departures.

2. A 450-mm upper concrete slab $\left(R_{u p}=5.24 \mathrm{MPa}\right.$, $\left.E_{u p}=32400 \mathrm{MPa}\right)$, the service factor of which equals 0.85 (apron); 200-mm lower lean concrete

Table 3. Comparative results of slab thickness design in FAARFIELD and "Aerodrom 380"

\begin{tabular}{ccccccc}
\hline & \multicolumn{2}{c}{ Upper concrete slab thickness, $\mathrm{mm}$} & \multicolumn{3}{c}{ Pavement life, years } \\
\cline { 2 - 7 } Design case & SNiP 2.05.08-85 & FAARFIELD & Aerodrom 380 & SNiP 2.05.08-85 & FAARFIELD & Aerodrom 380 \\
\hline 1 & 420 & $433.9(440)$ & 450 & 20 & 30.4 & 20.3 \\
\hline 2 & 400 & $408.4(410)$ & 430 & 20 & 22.7 & 22.9 \\
\hline 3 & 420 & $424.6(430)$ & 440 & 20 & 26.7 & 24.7 \\
\hline 4 & 370 & $390.9(400)$ & 390 & 20 & 29.2 & 26.1 \\
\hline 5 & 370 & $385.1(390)$ & 390 & 20 & 24.7 & 23.0 \\
\hline
\end{tabular}

Notes: In the FAARFIELD computer program, the upper concrete slab is modeled as a PCC overlay that is fully unbounded (its strength equals the standard concrete flexural strength measured on 28 days multiplied by the service factor); the lower lean concrete slab is modeled as a PCC slab (SCI $=40$, strength value of $3.45 \mathrm{MPa}$ ); the stabilized base is modeled as a variable stabilized base (rigid). FAARFIELD produces an upper concrete slab (PCC overlay fully unbounded) the thickness of which must be rounded to the nearest $10 \mathrm{~mm}$ (AC 150/5320-6E). The rounded upper concrete slab thickness is represented in the brackets. SNiP 2.05.08-85 pavement life equals the design life. FAARFIELD pavement life is calculated for the rounded upper concrete slab thickness. 
$\operatorname{slab}\left(R_{l w}=2.09 \mathrm{MPa}, E_{l w}=17000 \mathrm{MPa}\right) ; 150-\mathrm{mm}$ stabilized base $\left(E_{s b}=1950 \mathrm{MPa}\right)$, and Winkler foundation $\left(60 \mathrm{MN} / \mathrm{m}^{3}\right)$; the design aircraft is an A380-800 WV002 with the maximum ramp weight of $571 \mathrm{t}$, and 5000 annual departures.

3. A 420 -mm upper concrete slab $\left(R_{u p}=5.24 \mathrm{MPa}\right.$, $\left.E_{u p}=32400 \mathrm{MPa}\right)$, the service factor of which equals 0.85 (apron); 200-mm lower lean concrete $\operatorname{slab}\left(R_{l w}=2.09 \mathrm{MPa}, E_{l w}=17000 \mathrm{MPa}\right) ; 150-\mathrm{mm}$ stabilized base $\left(E_{s b}=1950 \mathrm{MPa}\right)$, and Winkler foundation $\left(60 \mathrm{MN} / \mathrm{m}^{3}\right)$; the design aircraft is an A380-800 WV001with the maximum ramp weight of $512 \mathrm{t}$, and 10000 annual departures.

The anticipated life of a concrete airfield pavement calculated by "Aerodrom 380 " is about $70 \%$ of the FAARFIELD pavement life (see Table 4).

In Table 5, the features of computer program "Aerodrom 380" are shown in comparison with the Ukrainian Standard (SNiP 2.05.08-85) and the FAARFIELD computer program.

The main benefit of the "Aerodrom 380" computer program is the design factor that allows using both maximum bottom and top tensile stresses.

\section{Conclusions}

The empirical formulas for the calculation of tensile stress at the top of a concrete slab and for determining the coverages to failure using the criterion of top tensile stress have been obtained.

The introduced computer program "Aerodrom 380" provides a practical approach for computing a two-layer concrete pavement under the impact of an A380 main landing gears and takes into account such factors as multiple-wheel interaction, finite slab size, and multilayer construction.

Table 4. Pavement anticipated life

\begin{tabular}{ccc}
\hline \multirow{2}{*}{ Design case } & \multicolumn{2}{c}{ Pavement anticipated life, in years } \\
\cline { 2 - 3 } & FAARFIELD & Aerodrom 380 \\
\hline 1 & 17.7 & 8.13 \\
\hline 2 & 19.1 & 13.8 \\
\hline 3 & 16.1 & 11.3 \\
\hline
\end{tabular}

"Aerodrom 380" uses the maximum tensile stress at the bottom and top edge of the concrete slab as design factors. The Ukrainian Standard and the FAARFIELD computer program have only one design factor (maximum tensile stress at the bottom of the concrete slab).

The "Aerodrom 380" computer program's solutions are compared to other solutions using the Ukrainian Standard, "LIRA-SAPR", software and the FAARFIELD computer program. The top to bottom tensile stress ratio increases when the subgrade ratio goes up.

The "Aerodrom 380" computer program contains a one-staged concept and lateral wander of aircraft traffic (probability factor $P\left(V_{W G}\right)$ or $\left.P C R\right)$. It uses different $P C R$ values for every weight variant (WV) of the A380-800. The FAARFIELD computer program operates with one $P C R$ value and changes the tire pressure automatically, when the user increases or decreases the take-off weight of the A380-800. The tire pressure calculated by FAARFIELD does not coincide with real values. The FAARFIELD aircraft's database does not include all weight variants of the A380-800 and an engineer has to set the required take-off weight manually.

"Aerodrom 380" uses the A380-800 technical characteristics based on official data (Airbus 2014).

The anticipated life of a concrete airfield pavement calculated by the computer program "Aerodrom 380" is about $70 \%$ of the FAARFIELD pavement life. The concrete slab thickness determined by the computer program "Aerodrom 380" is greater than the slab thickness calculated by the FAARFIELD computer program and the Ukrainian Standard. Based on the research results, computer program "Aerodrom 380" will have to be improved for the design of concrete airfield pavement thickness.

\section{References}

AC 150/5320-6E. Airport pavement design and evaluation. US Department of Transportation, Federal Aviation Administration, 2009. USA Standard.

Airbus. 2014. A380. Aircraft characteristics - airport and maintenance planning [online]. Airbus S.A.S., France [cited 25 November 2015]. Available from Internet: http://www. airbus.com/fileadmin/media_gallery/files/tech_data/AC/ Airbus-AC-A380-Dec2014.pdf

Table 5. Airfield concrete pavement design methods

\begin{tabular}{|c|c|c|c|c|c|}
\hline \multirow[b]{2}{*}{ Method } & \multicolumn{2}{|c|}{ Design factor } & \multirow[b]{2}{*}{ Design aircraft } & \multirow[b]{2}{*}{ Traffic mixture } & \multirow[b]{2}{*}{ Fatigue model } \\
\hline & $\begin{array}{l}\text { maximum bottom } \\
\text { tensile stress }\end{array}$ & $\begin{array}{l}\text { maximum top } \\
\text { tensile stress }\end{array}$ & & & \\
\hline SNiP 2.05.08-85 & + & - & + & - & - \\
\hline FAARFIELD & + & - & - & + & two-staged \\
\hline Aerodrom 380 & + & + & + & - & one-staged \\
\hline
\end{tabular}

Notes: The fatigue model of the FAARFIELD computer program is two-staged (Bin, Balbo 2014). 
Airbus. 2005. A380 Pavement Experimental Programme. Rigid phase. Rigid P.E.P Brochure. Airbus, Toulouse [cited 24 November 2015]. Available from Internet: http://www.airbus. com/fileadmin/media_gallery/files/tech_data/Pavement/ A380_PEP_Rigid_Brochure_Jan2005.pdf

Avtorske svidotstvo Ukraine. 2014. Computerna programa "Aerodrom 380". Rodchenko O. V. (Ukraine). No. 57948, data reestratsiy 30.12.14.

Bin, C.; Balbo, J. 2014. Comparing results of airport pavement concrete slab design using damage models of FAARFIELD to MEPDG concrete fatigue model, in 2014 FAA Worldwide Airport Technology Transfer Conference, 5-7 August 2014, Atlantic City, USA [online], [cited 24 November 2015]. Available from Internet: http://www.airtech.tc.faa.gov/ ATT2014/Papers/P10049\%20-\%20Bin\%20\&\%20Balbo.pdf

Davis, J. 2012. Overview of AC 150/5320-6E. Airport Pavement Design and Evaluation, in FAA Runway Safety and Pavement Maintenance Seminar for Africa, 8-10 February 2012, Lagos, Nigeria.

Evangelista, F.; Roesler, J. 2008. Is top-down cracking critical on airfield rigid pavements?, in 9th International Conference on Concrete Pavements, 17-21 August 2008, San Francisco, California, USA.

Fabre, C.; Balay, J. M. 2008. The airbus pavement experimental programme and high tire pressure test, in $3 r$ International Conference APT 2008, 30 September - 3 October 2008, Madrid, Spain.

Guo, E.; Hayhoe, G.; Brill, D. 2002. Analysis of NAPTF traffic test data for the first-year rigid pavement test items, in 2002 FAA Airport Technology Transfer Conference, May 2002, Atlantic City, USA [online], [cited 30 November 2015]. Available from Internet: http://www.airporttech.tc.faa.gov/ Download/Airport-Pavement-Papers-Publications-Detail/ $\mathrm{dt} /$ Detail/ItemID/16/Analysis-of-NAPTF-Traffic-Test-Data-for-the-First-Year-Rigid-Pavement-Test-Items

Guo, E.; Pecht, F. 2006. Critical gear configurations and positions for rigid airport pavements - observations and analysis, in Pavement Mechanics and Performance, GeoShanghai International Conference 2006, 6-8 June 2006, Shanghai, China, 7-14. http://dx.doi.org/10.1061/40866(198)2

Guo, E.; Pecht, F. 2007. Application of Surface Strain Gages at the FAA NAPTF, in 2007 FAA Airport Technology Transfer Conference, April 2007, Atlantic City, USA [online], [cited 27 November 2015]. Available from Internet: http://www. airtech.tc.faa.gov:9805/NAPTF/att07/ 2007/\%20Papers/ P07078\%20Guo\&Pecht.pdf

Guo, E. 2013. PCC Pavement Models in FAARFIELD Today and Tomorrow, in Federal Aviation Administration Airport Pavement Working Group Meeting, 15-17 April 2013,
Atlantic City, USA [online], [cited 30 November 2015]. Available from Internet: http://www.airporttech.tc.faa.gov/ Airport-R-D/Conference-and-Workshop/Airport-RDConference-Detail/dt/Detail/ItemID/302/PCC-PavementModels-in-FAARFIELD-Today-and-Tomorrow-

HoSang, V. 1975. Field Survey and Analysis of Aircraft Distribution on Airport Pavements. Report No. FAA-RD-74-36, Systems Research and Development Service Airport Division, Washington, USA [online], [cited 28 November 2015]. Available from Internet: http://www.airporttech. tc.faa.gov/Pavement/Downloads/rd74-36.pdf

Ricalde, L. 2007. Analysis of HWD data from CC2 Traffic Tests at the National Airport Pavement Test Facility, in 2007 FAA Airport Technology Transfer Conference, April 2007, Atlantic City, USA [online], [cited 30 November 2015]. Available from Internet: http://www.airporttech.tc.faa. gov/Airport-R-D/Conference-and-Workshop/AirportRD-Conference-Detail/dt/Detail/ItemID/365/Analysis-ofHWD-Data-from-CC2-Traffic-Tests-at-the-National-Airport-Pavement-Test-Facility

Rodchenko, O. 2013. Computer technologies of finite element modeling of airfield rigid pavement, in Proceedings of the 16th Conference for Junior Researchers 'Science - Future of Lithuania', Transport Engineering and Management, 8 May 2013, Vilnius, Lithuania, 65-70.

Rodchenko, O. 2014. Improvement of the two-layer airfield rigid pavement design, in Proceedings of the 17th Conference for Junior Researchers 'Science - Future of Lithuania', Transport Engineering and Management, 8 May 2014, Vilnius, Lithuania, 32-36.

Roesler, J.; Evangelista, F.; Domingues M. 2007. Effect of Gear Positions on Airfield Rigid Pavement Critical Stress Locations, in 2007 FAA Airport Technology Transfer Conference, April 2007, Atlantic City, New Jersey, USA [online], [cited 30 November 2015]. Available from Internet: http:// www.ceat.illinois.edu/PUBLICATIONS/presentations/ ROESLER\%20Rigid_PCC_stresses_Roesler.pdf

Roesler, J.; Evangelista, F. 2010. Top-down cracking predictions for airfield rigid pavements, in 2010FAA Worldwide Airport Technology Transfer Conference, 20-22 April 2010, Atlantic City, New Jersey, USA [online], [cited 30 November 2015]. Available from Internet: http://www.airtech.tc.faa.gov/ATT2010/ Pavements/Session3a/Evangelista-Top\%20Down\%20Cracking\%20on\%20Airfield\%20Rigid\%20Pavements.pdf

SNiP 2.05.08-85. Aerodromy [Airfields]. Ukrainian Standard.

Stepushin, A. 2001. K obosnovaniyu srokov slyzhby zestkih aerodromnyh pokrytiy iz tsementobetona, in Proectirovanie, stroitelsvo i ekspluatatsiya sooruzheniy aeroportov: sb. nauch. trudov MADI (TU). Moskwa, 12-18 (in Russian). 